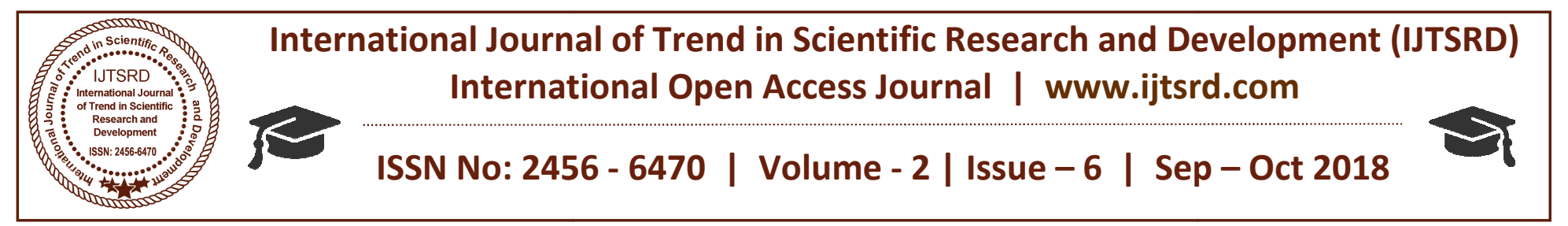

\title{
Trade War - An Overview
}

\author{
K. P. Manish ${ }^{1}$, S. S. Sanjay Krishnan ${ }^{2}$ \\ ${ }^{1}$ BBA; LLB (Hons), ${ }^{2}$ B.COM; LLB (Hons) \\ Sastra, Thirumalaisamudhram, Thanjavur, Tamil Nadu, India
}

\begin{abstract}
This article provides a detailed and peculiar view about the economic phenomenon 'Trade war' and its history from the times of The Great Depressions and moves on to the contemporary U.S.-China trade war and its impact on the global economic scenario. It also provides a wide view of the current scenarios of the ongoing trade war between two major countries that have the most humongous economies in the world that is U.S. \& China. The authors have unraveled major information about the first-ever trade war which was started by Reed Smoot \& Hawley which is followed by information about the onset of the ongoing trade war of U.S. \& China with the major events that followed during 'Code Red' which have been discussed in a chronological manner. Following which the authors have enlightened upon the economic position of India along with other countries and subsequently the effects of the Trade war on the Indian economy. The authors have also discussed the limitations of the practice of trade war to an extent.
\end{abstract}

\section{KEYWORD: Trade war, Tariff, Retaliation}

\section{INTRODUCTION}

The Trade war is an economic clash arising out from an extreme safeguard mechanism wherein, States raise or put forth tariffs or other trade barriers against each country in retaliation to the trade barriers created by other parties. Increased safeguard of tariffs causes both the output of competitive nation's compositions to move towards their self-sufficiency position. Certain economists presume that economic protections are more costly than other measurements because they are most likely to intend a trade war. For instance, if a country $X$ was to raise tariffs, then a second country $\mathrm{Y}$, its competitor, in retaliation may raise tariffs similarly. An increase in the subsidies howsoever may be a difficult phenomenon to reciprocate in contrary of the foreign country. In general, few scholars have conveyed trade wars and protectionism as the main cause of some economic contingency, which in particular the Great Depression.

\section{THE GREAT DEPRESSION OF THE 1930s:}

The most used economic word in recent times which is the Trade war had its origin in the 1930s that is during the period of The Great Economic Depression. Trade war severed the effects of the Great Depression. Before that, in the late 1920s, the United States economy had made some exceptional gains or profits in production due to the electrification, which was a significant factor in the mass production. Horses and mules were replaced by motorcars, trucks, and tractors. One-sixth to one-quarter of the cultivatable land which was previously devoted to feeding the horses and mules were freed up, contributing to the surplus in agricultural produce. Although the nominal and real wages were increased, they did not keep up with the gains. Consequently the ability to produce exceeded the market demand; it is a condition that was variously termed as overproduction and under consumption. The famous Senator Smoot raised the contention that tariff on imports would overcome the problem of overproduction.

Howsoever, the United States of America had actually been running a trade account surplus, and notwithstanding manufactured goods imports were increasing, manufactured exports were increasing even faster. The exports in food had been steadily falling and were in trade account deficit. However, the value of imports in food was trivial over half that of manufactured imports. Reed Smoot is from the state of Utah in the United States and is Republican and chairman of the Senate Finance Committee. Wills C. Hawley was also a Republican from Oregon and chairman of the House Ways and Means Committee. 
While campaigning for the Presidential post in the year 1928, the main assurance of Herbert Hoover's was to provide help to blockade farmers in increasing the tariffs on agricultural produce. Consequently, Herbert Hoover won the election and the Republicans maintained a clear majority in the Senate and the house during the year 1928. When the cosmopolitan economies entered through the preliminary stages of the Great Depression in the late 1929s, the major goal of the United States was the protection of the American jobs and the agriculturists from the foreign competition. There was another tariff increase which was patronized by Reed Smoot within the United States of America in the year 1929, which became the Smoot-Hawley Tariff Bill also called as the Tariff Act of the 1930s. This act raised United States tariffs over 20,000 imported goods. The tariffs under the Smoot-Hawley Act of 1930 were the second-highest in the United States of America in 100 years, but it was only exceeded by a minimal margin of the Tariffs of 1828. The Tariff Act and the following retribution tariffs by America's trading partners were major factors of the lowering down of American exports and imports by more than half during the Great Depression of the 1930s. Anyhow the economists of the period did not by much, the combined view among the economists and historians were that "The road-map of Tariff Act of the 1930s aggravated the Great Depression."

The League of Nations gathered for the World Economic Conference at Geneva, Switzerland in 1927 , in which it was concluded in its final report that "the time has come to put an end to tariffs and to move in the counter direction". Tremendous debts and reparations could only be settled through gold, services or goods but the only item available on that scale was the goods. However, many of the delegates' governments did the contra positive, starting in 1928 when France passed a new tariff law system.

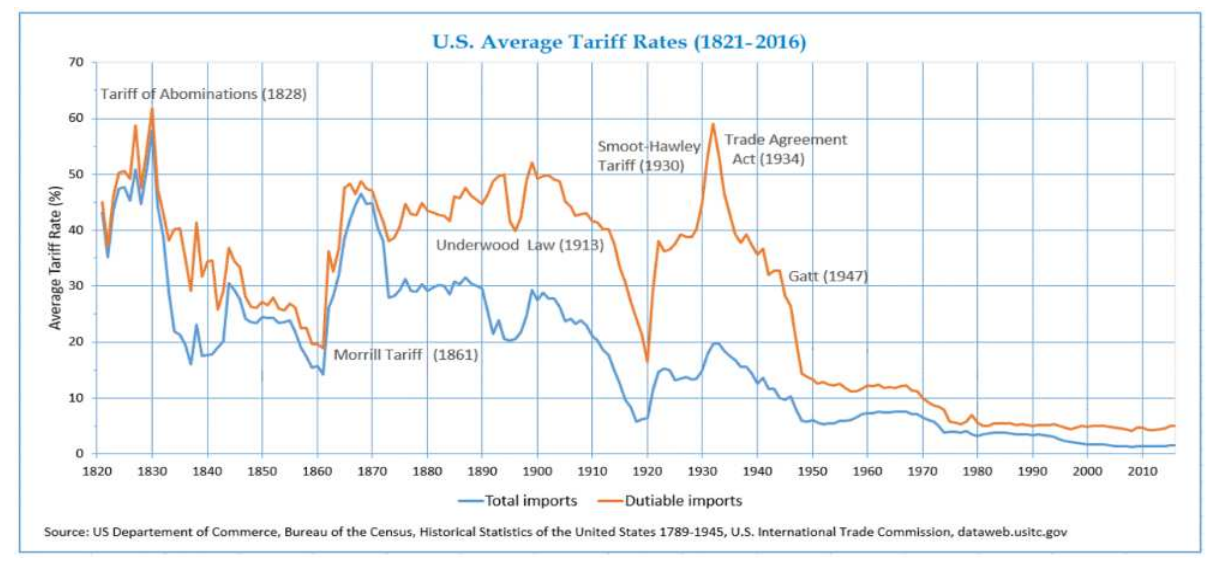

In the bi-volume series which was let out by the Bureau of Census, the United States entitled that "The Historical Statistics level of the United States in Colonial Times to 1970, Bicentennial Edition," tariff rates have been portrayed in a couple of forms. The "dutiable tariff rate" peak of 1932 was $59.1 \%$, second to the $61.7 \%$ rate in the year 1830 . Howsoever, in the year 1933, 63\% of all the imports were not taxed which the "dutiable tariff rate" didn't reflect. The "free and dutiable rate" in the year 1929 was at 13.5\% and topped under Smoot-Hawley Tariff Act in 1933 at the rate of $19.8 \%$ which is significantly below the $29.7 \%$ of "free and dutiable rate" that the United States averaged from the year 1821 until 1900, which is depicted in the above image which shows the tariff rate of the United States.

Firstly, the tariffs seemed to be a success. Howsoever, bigger economic problems survived in the demeanor of powerless banks. When the Creditanstalt, the famous bank of Austria failed in the year 1931, the global deficiencies of the Smoot-Hawley Tariff of 1930 became apparent in nature. Consequently, the United States of America imports decreased 66\% from $\$ 4.4$ billion in the year 1929 to $\$ 1.5$ billion in the year 1933, and the exports decreased to $61 \%$ from $\$ 5.4$ billion to $\$ 2.1$ billion. Gross National Product fell from $\$ 103.1$ billion in 1929 to $\$ 75.8$ billion in the year 1931 and bottomed out at $\$ 55.6$ billion in 1933. Imports from European countries decreased from 1929 at a high of $\$ 1.3$ billion to just $\$ 390$ million during 1932, while United States exports to Europe were decreased from $\$ 2.3$ billion in 1929 to $\$ 784$ million in 1932. Overall, the world trade decreased by some $66 \%$ between the year 1929 and the year 1934 . 


\section{THE ONSET OF U.S.-CHINA TRADE WAR}

With all the recent hostilities happening in and around the world, it's very easy to forget that China and the United States have been top trading partners for years. China outstrips Canada as the United States of Americas' largest trading partner, swanking with nearly $\$ 500$ billion in total imports and exports, about $15 \%$ of the total United States trade, in the year 2015. The U.S, showing contrasting reaction, who has been one of the top trading partner of China since the 1990s, overtook Hong Kong, which is the largest importer of Chinese merchandise goods in 1998. The trade relationship between the two economic powerhouses which was never smooth for a long time, it changed drastically when the United States Government imposed the first wave of tariffs on \$34 billion in Chinese goods, persuading an immediate retaliation from Beijing. If President Donald Trump's threats are to be taken seriously, then nearly one-third of Chinese imports to the United States could be affected by tariffs in the coming months. The period leading up to this week has been "very significant," said Mary Lovely, a non resident senior fellow at the Peterson Institute for International Economics and economics professor at Syracuse University. "This period represents a fundamental retreat by the leader of the global trading system," she said, "It will be seen as a turning point". ${ }^{1}$ Even during Trump's candidacy period, he made it bold and clear that he had planned systematically in a procedural way on renegotiating trade relations with China. During his speech announcing his candidacy on the year of 2015, Trump specified China 21 times, arguing that the country was taking away American jobs and "ripping" off the United States economy. Throughout his campaign, he beseeched to bring an immediate change in the growing trade deficit between the two nations by levying high tariffs, though, for a period of time, it seemed to be more like tough talk than action. Finally, the endless threat of tariffs by Donald Trump became a reality and came into action. Analysts say "The key is whether there will be more a second round of revenge and retaliation and a third round," said Shi Yinhong, a professor of international relations at Renmin University in Beijing. ${ }^{2}$

\section{MAJOR EVENTS OF 'CODE RED'}

$>\quad$ The very initial stage of the trade war was initiated when the President of the United States, Trump had decided on investigating the countries imports. As of which on $20^{\text {th }}$ April 2017, the Trump government had administered on launching an investigation into steel imports. This initial investigation, further led to another investigation on $27^{\text {th }}$ April 2017, over aluminum imports. So on an overall aspect, these two investigations intended in the initiation of the trade war, but as days passed, around August month the US administration had launched an investigation into intellectual property theft by China. As things heated up on $22^{\text {nd }}$ January 2018, President Trump had imposed new tariff over solar panels, which was a vital industry for Chinese exports. In his first tariff establishment, he initiated tariffs on washing machines and solar panels. The taxes for solar panels will take off at 30 percent for the first year before falling to half of that over four years. In spite of the establishment of tariff because of lack of communication, China's production occupies the world's solar module by 65 percent. The other major encounter on the trade war was on $1^{\text {st }}$ March 2018, when the US President Donald Trump had hiked tariffs on steel and aluminum imports. After imperiling the Chinese government for months, Trump raises the tax on aluminum and steel over 10 percent and 25 percent, respectively. Most importantly, the use U.S import from China only 6 percent in Toto, which makes the country to respond with the stern warning. Hua Chunying, the Chinese spokeswomen in a news conference in Beijing stated that the Chinese government will take proper and required measures to safeguard its legitimate rights and interests. Just as an infamous quote "True to the word that Revenge is a dish that is best served cold", China waiting for the right moment took charge of the circumstance and proposed tariffs against the United States for a week of April 2-6, 2018 which significantly escalated tension among the nations. It took a week for the Chinese government to strike down the international market. On $2^{\text {nd }}$ April 2018, China proposed tariffs on $\$ 2.4$ billion in United States exports. The list prepared by the Chinese government consisted of 128 goods in return for the tariff brought by Trump administration over Chinese aluminum and steel being imported for an amount to $\$ 2.7$ billion worth. The line up framed by Chinese government also targeted agricultural products such as pork, which have disproportionate over United States farmers. The author presumes the tariff brought up by the Chinese

\footnotetext{
${ }^{1}$ REPORT FROM WASHIGNTON POST.

${ }^{2}$ REPORT FROM WASHIGNTON POST.
} 
government had unfavorably affected the American market. The U.S government retributed massively by unleashing a list of 1,300 Chinese goods which were taxed over 25 percent as on April 3. China is targeting to achieve "Made in China 2025" according to which its goal was to increase the core material of Chinese domestic content over 70 percent within 2025. The strategic plan aimed at the pharmaceutical industry and other high technology industry. The outline of U.S government which they decided to impose tariff consisting of 1,300 Chinese items which had a value of about $\$ 50$ billion, which included goods like semiconductor, medical devices and other devices of the pharmaceutical industry and flat-screen televisions. The Chinese government had other plans to attack and this time as on April 4 they responded by exposing a list of 106 goods, which included airplanes, cars and soybeans etc, which was for a tariff for 25 percent. But on April 5, it was an official announcement by both the nations as the U.S President Donald Trump had ordered his chief trade negotiator Robert E. Lighthizer, the current member of U.S. Trade Representative for expanding tariffs to an addition of $\$ 100$ billion but after discussion, no new duties were imposed. Similarly, Zhong Shan, Commerce Minister of China at a press conference on April 6 that China will give tough competition of the tariffs proposed by Trump administration at any cost. After such an open announcement of war among two nations who have a highly developed economy, it was clearly understood by other foreign countries including India, that conflict in markets would surely adversely their economy. The Corporation of Zhong Xing Telecommunication Equipment ZTE which is also known as ZTE is a China-based system and Equipment Company. Moreover, it is China's leading telecom manufacturers. The ZTE Corporation is the largest manufacturers of the smart phone in the Chinese market. United States had fined the ZTE Corporation of about $\$ 1.19$ billion and penalizes the employees for infringement of trade sanction for illegally exporting their technology to North Korea and Iran. In $6^{\text {th }}$ April 2018, the U.S. Department Of Commerce had forbidden exports of telecommunication technology for seven years because the corporation failed to rightly reprimand the employees caught up in the scam, although the removed four senior employees they had still kept the rest of the members who were responsible for the disclosure of sensitive information that could endanger the territorial economy or political security and stability of a country which is explicitly prohibited by international law. The authors as already elucidated the scenario of ZTE Corporation, around the month of May, had announced to terminate their major operating activities since they had a financial loss which had caused by the ban imposed by United States Administration. After such a decision taken by ZTE Corporation, U.S President Donald Trump responds by tweeting that he feels sorry for the Chinese employees who would have lost their jobs and he also mentioned necessary arrangements are made with Chinese President $\mathrm{Xi}$ Jinping to bring back the deal with ZTE Corporation. Certain write-up told that Trump governments were working on to get certain concession relating trade in exchange for helping ZTE Corporation. Some officials of national security had the concern of leaking of U.S technology would lead to cybersecurity threats. The Democratic senator expressed their concern through a message to Trump regarding the decision taken by Trump saying the national security of America shall not be taken as a bargaining chip under the conflict of trade negotiation. They also stated by approving the trade with China just for the sake of promoting a job in China is a bad decision since the job immunity for American workers would be in jeopardy. Finally, U.S. President decides to liberalize the ban imposed over ZTE Corporation, as on June 7. The seven years ban was taken within a month on selling of goods to ZTE Corporation. The Commerce Secretary Wilbur Ross had stated that instead of forbidding the company, they are willing to pay $\$ 1$ billion fine along with accommodating new employees from U.S staffs. After this understanding, the trade war was once again brought forward by the United States government by announcing tariff on Chinese goods worth $\$ 50$ billion for 25 percent. After the war is to be compromised by the United States removing their ban over ZTE Corporation, things appeared to be smooth among two nations, but the U.S President Donald Trump had extended his listing of about 1,100 Chinese goods. The Chinese government in return issued a list of $\$ 50$ billion of United States product; the list consisted of goods from the agricultural sector and moreover those areas where Trump is holding high vote base. This provoked Donald Trump to go against the Chinese government soon $8^{\text {th }}$ of June he had jeopardized to levy additional tariffs of worth $\$ 200$ billion of Chinese goods. When asked to him, he stated that the administration is compiling the record of goods of China which would face 10 percent less of tariff until China government agrees to the trade concession 
brought up by the United States Administration. The effect of implementation of Trump's thought would increase to $\$ 200$ billion of import tax for the country, by way of explanation it brings a conclusion that almost Chinese goods are being imposed tariff of worth $\$ 505$ billion is been imported to the United States. Gao Hucheng, Trade Minister of China stated that Trump's statement was blackmailing the Chinese government. Meanwhile, the house of senate decides to backtrack on the decision taken by President Trump over ZTE Corporation, and the result showed 85 percent of the vote to re-establish the ban applied over the trade deal of United States Technological components to that corporation. Trump calls on the Congress government to intensify the review process of the Chinese investment in the United States. As per the report, it stated that the Trump's administration was planning as to bar firms of China from letting them invest on United States Technology. But the government stopped abruptly stating it would work out with Congress so as to tighten the regulations happening around foreign investment. As of $6^{\text {th }}$ July, Trump's authority imposes tariff over Chinese goods worth $\$ 34$ billion. The United States government had fixed 25 percent tax over the Chinese goods hoping that the Chinese government in reciprocation would fix 25 percent tariff over American goods of worth $\$ 34$ billion. Beijing retaliates over the United States goods because of the tariff imposed by the Trump administration. JACK DANIELS was one of the major United States imported goods which had high tariff rate, which affected the market adversely. The Beijing President in a press conference commented about Trump's administration as a bunch of hoodlums. The tariff imposed as on $6^{\text {th }}$ July had majorly affected the machinery industry and the electronic hub such as LED and computer hard drives. As on $1^{\text {st }}$ August, the Trump government plans to double the value of tariffs imposed on Chinese goods. The goods worth of $\$ 16$ billion of Chinese goods which were initially taxed for 10 percent is shot to 25 percent in a bid to pressure Beijing into making trade concessions. They have a given a deadline for imposing the hike in tariff rate till the deadline of August $23^{\text {rd }}$ according to United State Trade Representatives (USTR).

$>\quad$ India has made up a plan to exports goods to China and has identified more than 40 products where it's in a position of advantage to replace and capture the United States market share that has become costlier in light of the trade spat between the world's two biggest economies. The 40 products would include flue-cured tobacco, fresh grapes, cotton linters and alloy steel seamless boiler. This major export would boost up the Indian economy and reduce $\$ 63$ billion trade deficit that India has with China. It also recently started purchasing soybean from Brazil after cutting a $25 \%$ tariff on the oilseed's shipment from the United States as the trade tensions between the two nations intensified. The meetings between officials of the United States and China the previous week made a little headway, setting the stage for the United States to push ahead with the next round of tariffs up to $\$ 200$ billion worth of Chinese Goods.

\section{POSITION OF INDIA ALONG WITH OTHER COUNTRIES ON A FULL-BLOWN TRADE WAR:}

India will not be able to afford to retaliate against the United States unlike the European Union and China as it is a major export destination for the country. Cosmopolitan trade which is already in a still phase, faces a lack of vegetation future as United States President Donald Trump threatens countries to move ahead with his agenda of protection, which is a move that could provoke strong retribution from the United States' trading partners and take over the fate of the struggling World Trade Organization (WTO).Over the last two years, the multilateral trade rule-setting has been under attack from the United States, which is its one of its most influential member.

India the country which realized and saw its exports jump by five-fold between the year 2001-02 and 2010-11 because of the liberalized global trade The country now stands to lose a lot if there is a fullblown trade. The European Union and China, for example, have already realized the United States exports which they should target if Donald Trump carries out his threat to increase import duty on steel by $25 \%$ and aluminum by $10 \%$ respectively. Brazil, Korea, Canada, and Russia too could retribute against the United States trade protectionism of the President.

Because of the country's significant trade surplus, India too is under the United States scanner and its exports would attract more punitive tariffs on failing of trade diplomacy. Moreover, India critically depends on the United States to meet their defense requirements. Growing protectionism by the United States of America over the last decade has already had a negative effect on global trade. 
For instance, world merchandise exports grew by a slight of $1.4 \%$ between the year 2010 and the year 2016, as per the data compiled by the World Trade Organization. Between the year 2013 and the year 2016 alone, world merchandise export has annually been grown by a nominal $0.5 \%$ between 2013 and 2016. In fact, the merchandise exports fell by a short of $3.3 \%$ to $\$ 15.464$ billion in 2016 from the year previous to it. A quantum that is far more than the $0.4 \%$ decline is reported in the world Gross Domestic Product. In consideration, during the year 2001-2010 global merchandise trade had its growth by $63 \%$. Annual exports had its growth of $4.3 \%$ during the period, even as average Gross Domestic Product growth was comparatively modest at $2.5 \%$. India has confirmed to these trends. For instance, the country's exports had a growth of $468 \%$ between the year 2001-02 and 2010-11. But after that, the years have been much disappointing. Between the year 2010-11 and 2016-17, the country's exports grew by a trivial 10\%. India recorded a $40 \%$ rise in its exports on textiles in the year 2010 and became the third largest exporting nation of the world, ahead of the United States. Since the time of IInd World War, the global merchandise trade has gradually grown about 1.5 times faster than that of world Gross Domestic Product. But in the late 1990s, it grew more than twice as rapid. For the first time ever since the year 2001, this ratio dropped to 0.6 which is first time below 1 in the year 2016. It is projected that it would recover it partly in the year 2017 but the further moving of trade very slowly relative to Gross Domestic Product remains the main cause for concern.

India has brought in 16 more steel goods and products under the quality control order, a move which could restrict the imports and hurt the consumer industries but provide help for the internal steel manufacturers. In consonance to the statement issued by the ministry of steel, exporters of the 16 goods and products are to record their exports themselves with the Bureau of Indian Standards (BIS) mandatorily. It would finish up being a long, lengthy and complicated process which could reduce foreign suppliers.

Consequently, after the issuance of the new notification by the ministry of steel, 50 or more steel products, or nearly $90 \%$ of the product lines, have been covered under the order of the ministry. The remaining balance would be brought under quality order control soon by the ministry of steel. The manufacturers of automobile components have already felt the pinch of the control mechanism which is because of the quality compliance which was stipulated by the steel products used by the industry and firms as raw materials in their components.

From early 2015, the government of the Hon'ble Prime Minister Narendra Modi has proactively taken many measures like anti-dumping, minimum import price and safeguard besides quality control to check the steel imports and to support the domestic manufacturers who are bleeding because of the cheaper imports from various countries.

India unveiled or put forth a new National Steel Policy in the month of May 2017, which aims at raising the capacity of steel production from about 100 million tons as of now to 300 million tons by 2030, which would entitle some additional investment of Rs 10 lakh crore. The National Steel Policy seeks to raise the per capita consumption from the present $60 \mathrm{~kg}$ to $160 \mathrm{~kg}$ by the year 2030 .

The trade war between the United States and China has put forth enough signs of escalation, with both economic powerhouses employing retaliatory tactics for the purpose of imposing tariffs in the last few months. In the Asian continent, China is the largest buyer of crude oil and natural gas. The biggest trader or trading house of China has already stopped importing or buying United States crude oil and the countries capital Beijing look ready to slap retributory tariffs on the United States crude and Liquid Natural Gas. The stooping of buying United States oil refers to the continuous purchase of Iranian oil which means keeping Tehran in play in the global or cosmopolitan trade. The tautness between China and the United States may partially lower down the effect of Iran sanction on oil sourcing to India. Meanwhile, in the month of August, a total of 9.94 million barrels which is about 319,000 barrel per day imported over the first seven months, of crude oil from the United States has been booked by India according to vessel tracking and port data compiled. This is almost triple the rate or amount in the month of July. Many Industry users say that India may enjoy a good amount of bargaining power to argue for a United States waiver. India is globally the world's third largest importer of crude oil and if it cuts its purchases from Iran the other likely major 
beneficiary of the United States is Tehran's regional rival, Saudi Arabia.

China also has taken over the support of the more important biggest developing nations which includes India to push back against the protectionism as United States president Donald Trump who threatens to impose tariffs on almost all Chinese imports. Brazil, Russia, India China, and South Africa have come together and agreed to dispute against the trade protectionism altogether after the meeting during the Group of 20 summits (G20) of the finance ministers and the central bankers in the Buenos Aires. Finance Minister Liu Kun said that the BRICS in full force should support the economic multilateralism and globalization and should oppose unilateralism and protectionism in any form. These comments came after Donald Trump said "ready to go" with the $\$ 500$ billion in the tariffs on imports from China and accused the European Nation and the Asian Nation for weakening their currencies to obtain some trade benefits.

\section{EFFECTS OF TRADE WAR ON INDIA}

To start with, the impact of the trade war, it is not a trade between the two countries, but in reality, it spreads across various countries. A basic logic could be applied to understand this, let us take a situation where in a country $\mathrm{X}$ has produced an excessive amount of goods to export to country Y, but the tariff imposed by country $\mathrm{Y}$ is high, which affects country X's economy. As a result of which, country $\mathrm{X}$ decides to export their produced good to another country for avoiding deflation of their country and most importantly avoid from paying high tariff rate for exporting to country Y. Such is the situation which is faced by other countries because of this trade war. The impact of this trade war maybe of two ways- direct or indirect. For India, the impact of trade war is more of indirect way than directly.

Here are 6 ways in which India could get impacted by the US-China trade war:

$>$ There was a major drop in the stock market immediately after the trade war was announced. As imports become more expensive due to a trade war, manufacturers will find it increasingly hard to manage their margins and this will force a slowdown in output. As more and more countries impose tariffs, higher import costs will get transmitted seamlessly. The International Monetary Fund had alerted that the expected growth rate was 3.9 percent for 2018, because of the negative impact of the trade war.

Trade deficit could be the big casualty in the Indian context. India has already seen its monthly trade deficit approaching the $\$ 15$ billion mark in the last few months. The current year could see full-year trade deficit at over $\$ 200$ billion and imports at well over $\$ 600$ billion. The forex reserves may be adequate to cover just about 9 months of imports. A trade war will widen the trade deficit, make imports more expensive and reduce the forex cover.

A logical corollary of this wider trade deficit and higher import prices will be imported-inflation. When inputs get costlier, it gets imputed into the final cost of manufacture in the form of higher cost of production. That adds to producer inflation, and this trend is already obvious in many countries. As inflation moves higher, we could see a sharp fall in the domestic purchasing power and that could further depress the real rate of growth.

When inflation moves up, it has the tendency to push up the inflation expectations. Normally, inflation expectations are the key to interest rates and as a result, the RBI may be constrained to increase the repo rates. With inflation going up across the world, we could see a situation where the global bond yields start moving up and the RBI may not have much of a choice except to raise rates sharply to prevent capital outflows.

The INR could come under pressure in the global currency markets. There is a limit up to which the RBI can manage the rupee. Normally, trade wars tend to degenerate into currency wars. That is because as every country starts imposing higher tariffs on imports, they also try to boost exports by weakening the currency. While it starts as a defensive exercise, it eventually turns into a currency war. A sharp depreciation in the INR could trigger risk-off capital flight. That is not a great situation as we saw in 2013 .

Last, but not the least, India could risk corporate bankruptcies as an outcome of these trade wars. The companies of India could get squeezed between two extremes. On one hand, prices of inputs will go up due to higher import costs. The companies will either have to pass on the burden to the customer (which may not be possible in most cases) or absorb the costs. That will hit the margins. At the same time, higher interest rates 
will push them closer to financial vulnerability. This will be more so for high debt companies.

\section{TRADE WAR AND ITS LIMITATIONS:}

As said by everyone, every coin has two sides so do everything in the universe. Nothing in this world is of a single side. The Cosmopolitan or the Global competition keeps the prices of many goods and services down. Removing the Global competition from the market results in inflation. Even if the wages increase, they would be outstripped by the rise or increase in prices of the commodity. Free trade or Global competition allows access to a much wider range of goods and services, providing more choice to the consumers because there are a lot of goods that are not supplied or made by the domestic market. Tariff rates and protectionism limits choice of the customer which may include, customers may have to make use of the inferior products, and also certain foods being only available at certain times of the year like that of a flower which blooms only once a year. Many gains or advantages of the protectionism market are tend to be short-lived and counterproductive. For instance, if we introduce or raise the import tariffs rate on other country's goods, then it would be normally only a matter of time before they retribute and raise the tariffs on our exports. Many jobs of the people would be lost which rely on the exports of goods. If we close our border to that of other countries' products, they would obviously tend to lose theirs too. Jobs that mostly rely on the internet for their survival would be disappearing, as the tariff barriers for the free movement of capital and labor has gone up. Job outsourcing or outsourcing of work is a proportionate result of failure to invest in the field of education and skills in many cases. Taking for instance the United States has more shortages in high technology, science workers, and engineering because of the former said investment is very less that is it fails to educate its own people to some extent. Companies which are protected from the global competition would flourish in the short period of time, but in accordance with the long term, they would tend to become less efficient in nature. The Innovation and quality would decline over a specific period of time, as there is a minimal incentive provided to improve without the competition. On the purview of the author, the foreign importers in any way should cut the costs to allow for the tariffs and lower the quality of products for their income. The advocates of free trade mechanism have argued with some validation that the countries which have inter-meshed economies in them are less likely to go to the war with others. In a different circumstance, the general notion of protectionism can stir up conflicts among the nations. The protectionism periods have a historical nature of ending in an economic slump which would be the most notable Depression of the 1930's. The effects of tariff rates and trade war could be much wider than viewing it in a specific and targeted way. For example, a tariff rate on production of steel would push the prices of all the products and would increase the process which uses steels along with the whole steel industry itself. This would be the cons of the trade war on the author's point of view.

\section{CONCLUSION}

"ECONOMICS IS LIKE A MIRROR AND WILL REFLECT BACK TO THE THINKER WHAT HE

$$
\text { THINKS" }
$$

This article has been a mere elucidation on the effects of the U.S-CHINA trade war on the global economy and the multitude of counties that had been linked in the global economic scenario in the post-globalization era. The trade war just like any other economic phenomenon has had its own zeros and ones like the two sides of a coin. India has been in a unique position to experience both the sides of this coin and the resultant exchange of this coin has proceeded in the change in the domestic economic scenario of India. This article is hardly a conclave of ideas that met in this present scenario and the way of thinking the authors took to look at it.

\section{REFERENCES:}

1. Economic and Political Weekly

2. The Wire.

3. The Times of India.

4. The Hindu.

5. The Washington Post.

6. www.indiainfoline.com

7. www.ndtv.com

8. www.theguardian.com 